\title{
Sui Chinese
}

National Cancer Institute

\section{Source}

National Cancer Institute. Sui Chinese. NCI Thesaurus. Code C158183.

A Chinese person from the Sui ethnic group. 